\title{
The Role of Ryk and Ror Receptor Tyrosine Kinases in Wnt Signal Transduction
}

\author{
Jennifer Green ${ }^{1,3}$, Roel Nusse ${ }^{1}$, and Renée van Amerongen ${ }^{2}$ \\ ${ }^{1}$ Department of Developmental Biology and Howard Hughes Medical Institute, Stanford University, \\ Stanford, California 94305 \\ ${ }^{2}$ Division of Molecular Oncology, Netherlands Cancer Institute, 1066 CX Amsterdam, The Netherlands \\ Correspondence: r.v.amerongen@nki.nl
}

Receptor tyrosine kinases of the Ryk and Ror families were initially classified as orphan receptors because their ligands were unknown. They are now known to contain functional extracellular Wnt-binding domains and are implicated in Wnt-signal transduction in multiple species. Although their signaling mechanisms still remain to be resolved in detail, both Ryk and Ror control important developmental processes in different tissues. However, whereas many other Wnt-signaling responses affect cell proliferation and differentiation, Ryk and Ror are mostly associated with controlling processes that rely on the polarized migration of cells. Here we discuss what is currently known about the involvement of this exciting class of receptors in development and disease.

$T_{\text {a }}^{\text {he }}$ he role of the receptor tyrosine kinases Ror and Ryk in Wnt signaling should be considered within the larger group of Wnt signaling receptors. Historically, the Frizzled (FZD) and LRP5/6 molecules were the first proteins implicated as receptors for Wnt ligands (Clevers and Nusse 2012). FZD proteins consist of a seven-pass transmembrane portion and an extracellular cysteine-rich domain (CRD) (Bhanot et al. 1996). Wnt proteins bind with high affinity to the CRD in a fairly promiscuous way: One Wnt will bind to multiple FZDs and conversely, single FZDs can interact with multiple Wnts (Hsieh et al. 1999b; Carmon and Loose 2010). This lack of a high degree of spe- cificity is also borne out by the structure of the Wnt-CRD complex, as recently established for the Xenopus Wnt8 protein in a complex with the Frizzled8 CRD. Of the two domains on Wnt that interact with the CRD, one contains a palmitoleic acid modification, presumably present on multiple Wnt proteins, projecting into a pocket in the Frizzled CRD (Janda et al. 2012).

FZD molecules work together with two transmembrane LRP family members, LRP5 and LRP6 in vertebrates (Pinson et al. 2000; Tamai et al. 2000), both homologs of the Drosophila Arrow protein (Wehrli et al. 2000). The current model is that a Wnt protein binds to

${ }^{3}$ Present address: ActivX Biosciences, La Jolla, CA 92037.

Editors: Joseph Schlessinger and Mark A. Lemmon

Additional Perspectives on Signaling by Receptor Tyrosine Kinases available at www.cshperspectives.org

Copyright (C) 2014 Cold Spring Harbor Laboratory Press; all rights reserved; doi: 10.1101/cshperspect.a009175

Cite this article as Cold Spring Harb Perspect Biol 2014;6:a009175 
J. Green et al.

FZD and LRP at the same time, forming a dimeric/multimeric structure. This may result in a conformational change in the receptor molecules, which leads to phosphorylation of the LRP cytoplasmic domain by associated protein kinases. Phosphorylation of the LRP tail (He et al. 2004) takes place on several clusters of serines and threonines, each containing a PPPSP motif. The protein kinases involved include GSK3 and CK1 $\gamma$. GSK3 targets the PPPSP motif and phosphorylates a serine residue in that motif (Zeng et al. 2005). Residues adjacent to the PPPSP motif are phosphorylated by CK1 $\gamma$, a CK1 family member with a membrane anchor in the form of a palmitoylation domain (Davidson et al. 2005). The phosphorylation of LRP leads to binding of the Axin protein to the cytoplasmic tail of LRP6 (Mao et al. 2001), an event that increases cytoplasmic levels of the signal transducer $\beta$-catenin, which subsequently translocates to the nucleus and induces gene expression in complex with TCF/LEF transcription factors. On the cytoplasmic side, Frizzled interacts with Dishevelled (Dsh) (Chen et al. 2003; Tauriello et al. 2012), which in turn may promote interactions with Axin through the DIX domain that these two proteins have in common (Schwarz-Romond et al. 2007; Fiedler et al. 2011). Although signaling via the FZD and LRP5/6 receptors has occupied our attention for many years, the identification of receptor tyrosine kinases (RTKs) as additional Wnt receptors has opened the door to new and exciting discoveries of Wnt signaling in development and disease.

\section{Ror1 AND Ror2}

Ror1 and Ror2 were first identified in PCRbased screens for molecules with resemblance to tyrosine kinases of the Trk family (Masiakowski and Carroll 1992). Indeed, although Ror1 and Ror2 occupy a separate corner in the RTK dendrogram, they are more closely related to Trk and Musk RTKs than to other RTK proteins. However, this conservation is largely restricted to their intracellular tyrosine kinase domains; their divergent extracellular domains suggested early on that Ror1 and Ror2 might interact with a distinct set of extracellular ligands.

A distinguishing feature in the extracellular portion of the receptors is the presence of a CRD domain that bears close homology with the Wnt-binding domain found in Frizzled transmembrane receptors as well as in secreted Wnt inhibitors of the SFRP family (Saldanha et al. 1998), signifying that Wnt proteins might be the elusive ligands for this class of receptors (Fig. 1). It was not until much later, however, that this was definitively shown to be the case (Oishi et al. 2003; Mikels and Nusse 2006). In addition to the CRD, Ror proteins are further characterized by extracellular Kringle and immunoglobulin domains, whose functions remain enigmatic to this day, and by intracellular proline-rich and serine-threonine-rich domains (Masiakowski and Carroll 1992).

\section{Ror1 and Ror2 in Development}

Ror receptors are evolutionarily conserved across vertebrate and invertebrate species. The genomes of most species are reported to harbor two homologs.

\section{Flies, Worms, and Frogs}

Two Ror homologs, named Dror and Dnrk, have been described in Drosophila, but apart from their restricted expression pattern in the developing nervous system, no functional role for these receptors has been reported (Wilson et al. 1993; Makino et al. 1997). CAM-1, the sole Caenorhabditis elegans Ror homolog, is widely expressed in the nervous system, where it functions to regulate neuronal migration, positioning, and neurite outgrowth (Forrester et al. 1999; Zinovyeva et al. 2008; Hayashi et al. 2009; Kennerdell et al. 2009; Song et al. 2010) as well as synaptic transmission (Francis et al. 2005). CAM-1 also regulates the polarity of epithelial cells and stem cells (Green et al. 2008a; Yamamoto et al. 2011). Functions in cell polarity and cell migration are conserved in Xenopus, where $X$ Ror 2 regulates polarized cell migrations known as convergent extension (Hikasa et al. 2002; Schambony and Wedlich 2007). 
Ryk and Ror RTK in Wnt Signal Transduction

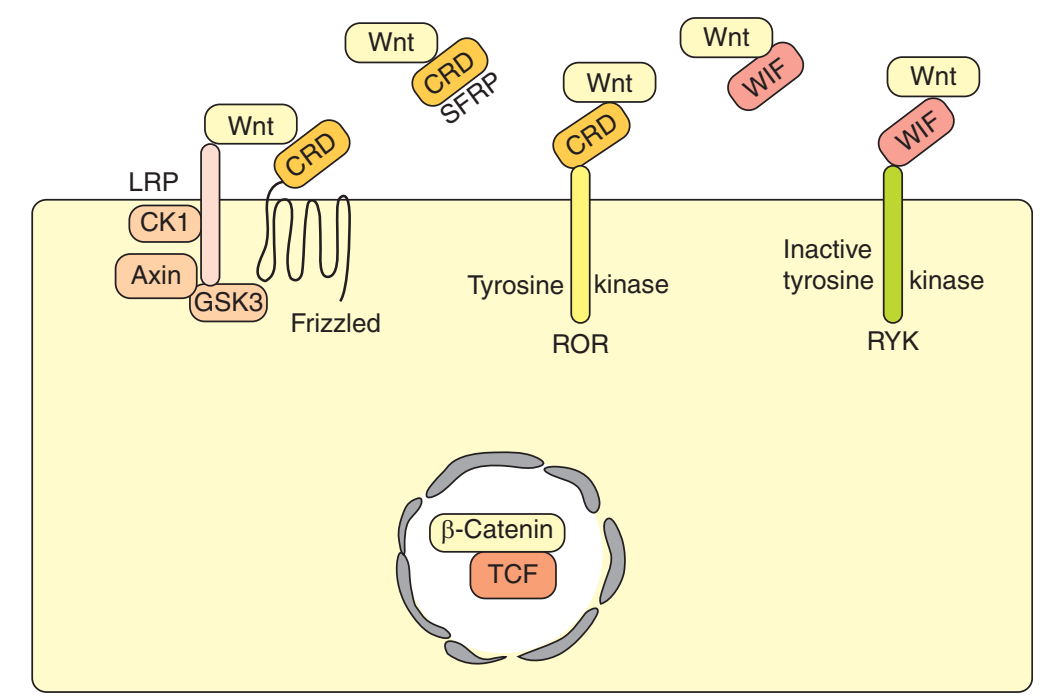

Figure 1. Schematic depicting the use of CRD and WIF domains in Wnt signal transduction. The mammalian genome encodes 19 different Wnts, which can mediate their signaling effects through 10 different FZDs that act in concert with the LRP5 and LRP6 coreceptors. The binding site for Wnt on Fzd is formed by the CRD. This motif is also used as the Wnt-binding site in members of the SFRP family of extracellular Wnt antagonists and in Ror 1 and Ror2, both of which are members of the RTK family. A second Wnt-binding module, the so-called WIF domain, is used by extracellular Wnt antagonists of the WIF family, as well as by Ryk, another RTK family member. In spite of possessing functional Wnt-binding domains it remains unclear how Ror and Ryk receptors function in Wnt signal transduction. They have been proposed to function as stand-alone receptors, but also as coreceptors together with Fzd. In addition, they have been implicated in $\beta$-catenin-dependent and -independent signaling responses. At present, the molecular mechanisms used by these RTKs to transmit the Wnt-signal are ill understood. Only Ror2 has been shown to have a functional kinase domain, but both Ror1 and Ryk have been proposed to function as pseudokinases. See text for details.

\section{Mammals}

Based on the fact that Ror1 and Ror2 were first cloned from a human neuroblastoma cell line and the fact that expression of the Drosophila homologs appeared to be largely restricted to the developing nervous system, the initial characterization of the expression pattern of the mammalian Ror proteins was also performed in neural tissues (Oishi et al. 1999). Indeed, both Ror1 and Ror2 play a role in maintaining neural progenitor cell fate in the developing mouse brain (Endo et al. 2012). However, Ror1 and Ror2 are expressed with partially overlapping expression patterns in a broad range of tissues during mouse embryonic development, including the skeletal system and internal organs (Al-Shawi et al. 2001; Matsuda et al. 2001). The expression of Ror2 appears to drop right before birth. In contrast, Ror1 expression could be detected at the RNA level in a limited number of postnatal tissues, although its expression too drops significantly in the adult (Oishi et al. 1999).

Mice deficient for Ror2 are born with craniofacial abnormalities as well as significantly shortened limbs and tail (DeChiara et al. 2000; Takeuchi et al. 2000), suggesting an important role in skeletal development. The gross appearance of Ror2-deficient and Wnt5a-deficient mice is quite similar, although loss of Wnt5a results in more severe defects than Ror2 (Yamaguchi et al. 1999; Ho et al. 2012). It was in fact this observation that first prompted scientists to investigate a role for Wnt5a in Ror2 signaling (see below) (Oishi et al. 2003).

In humans, mutations in Ror 2 are associated with brachydactyly type $B$ and recessive Rob- 
J. Green et al.

inow syndrome, both of which result in limb malformations (Afzal et al. 2000; Oldridge et al. 2000; Afzal and Jeffery 2003). More recently, mutations in Wnt5a were also discovered in patients with autosomal-dominant Robinow syndrome (Person et al. 2010), suggesting that this signaling axis is disrupted in these patients.

In addition to skeletal malformations, Ror2null mice have heart and lung defects (Takeuchi et al. 2000), a shortened intestine (Yamada et al. 2010), and aberrant inner ear hair cell orientation (Yamamoto et al. 2008). It should be noted, however, that some of these phenotypes might vary in penetrance and/or might be less pronounced in different mouse strains and/or on a different genetic background, as we have observed for the lung and inner ear defects in Ror2-knockout mice (RvA and RN).

The phenotype of mice deficient for Ror 1 is less severe than that of mice lacking Ror2. One study reported that these mice died within 24 hours after birth as a result of respiratory failure (Nomi et al. 2001), whereas another study reported more than half of these mice surviving until weaning, with a fair number of them reaching adulthood (Lyashenko et al. 2010). The additional loss of Ror1 exacerbates the Ror2-mutant phenotype, as mice lacking both Ror homologs show enhanced skeletal and cardiac abnormalities (Nomi et al. 2001). Of note, it was recently reported that these initial Ror1knockout mice might not represent true null mutants, as a trunctated Ror1 protein was still expressed from the targeted allele. Still, newly generated conditional Ror1- and Ror2-knockout mice largely recapitulate the previously described mutants and Ror1/Ror2 double-knockout mice largely recapitulate the Wnt5a-null phenotype (Ho et al. 2012).

\section{Ror1 and Ror2 in Cancer}

Both Ror1 and Ror2 have been ascribed oncogenic functions in cancer cells. In particular, siRNA mediated knockdown of Ror1 was shown to induce apoptosis in Hela cells, showing its importance for cell survival (MacKeigan et al. 2005). Ror1 was subsequently found to be overexpressed in B-cell chronic lymphocytic leukemia (CLL), possibly as a result of enhanced Stat3 signaling (Baskar et al. 2008; Daneshmanesh et al. 2008; Li et al. 2010). It enhances cell viability and might therefore be an attractive candidate for targeted therapy (Fukuda et al. 2008; Hudecek et al. 2010; Yang et al. 2011; Baskar et al. 2012; Daneshmanesh et al. 2012). Its role might extend to other B-cell lymphomas, as a reduction in Ror1 expression affects viability of CLL as well as lymphoblastic leukemia (ALL) cells (Tyner et al. 2009; Choudhury et al. 2010; Dave et al. 2012). Elevated expression of Ror1 was also detected in mantle cell lymphomas (MCLs), marginal zone lymphoma (MZL), and nonhematopoietic malignancies (Barna et al. 2011; Gentile et al. 2011; Zhang et al. 2012).

High levels of Ror2 have been detected in osteosarcoma, melanoma, and renal cell carcinoma cell lines and a reduction in Ror2 expression was shown to decrease cell invasion and motility and extracellular matrix remodeling (Enomoto et al. 2009; Morioka et al. 2009; Wright et al. 2009; O’Connell et al. 2010). Furthermore, Ror2 was recently shown to be a novel prognostic biomarker and potential therapeutic target in patients with leiomyosarcomas or gastrointestinal stromal tumors (Edris et al. 2012). Whereas Ror2 is primarily implicated in cell polarity and migration, it has also been associated with cell survival and proliferation. For example, restoration of Ror2 expression inhibited tumor cell proliferation in colon cancer, where Ror2 gene expression is reportedly frequently silenced (Lara et al. 2010). Thus, Ror2 may have tumor-promoting as well as tumor-inhibiting activities depending on the cellular context.

Unfortunately, the biochemical activities of these receptors remain ill defined. As such, there is a large knowledge gap in our understanding of the processes that are controlled by Ror in both healthy and diseased tissues and the molecular mechanisms that underlie them.

\section{Signaling Mechanisms and Effectors}

Ror2 has been shown to have an active tyrosine kinase domain and to function as a genuine 
RTK under at least some conditions (Masiakowski and Carroll 1992; Mikels et al. 2009). Like other RTKs, forced dimerization induces Ror2 tyrosine phosphorylation, whereas ligand binding can induce either tyrosine or serine/threonine phosphorylation (Liu et al. 2007; Yamamoto et al. 2007; Akbarzadeh et al. 2008; Liu et al. 2008; Mikels et al. 2009; Grumolato et al. 2010). In contrast, Ror 1 was found to lack tyrosine kinase activity and most likely functions as a pseudokinase (Masiakowski and Carroll 1992; Gentile et al. 2011).

An alternative splice variant of Ror 1, lacking both the extracellular and transmembrane domains, was identified in neural tissues and cancers (Reddy et al. 1996). This is interesting in light of a recent description that, similar to Ryk (see below), the Ror1 receptor might undergo cleavage resulting in a signaling portion that is directed to the nucleus by a signal located in the juxtamembrane domain (Tseng et al. 2010). The biological function of these truncated Ror proteins is unknown, although they have been reported to play a role in cell migration and remodeling of the actin cytoskeleton (Tseng et al. 2011).

It is widely appreciated that $\mathrm{Wnt} 5 \mathrm{~A}$ is a ligand for Ror2 (reviewed by Green et al. 2008b). At least one potential mechanism underlying Ror2 activation by Wnt5A was proposed recently by the finding that Wnt5A induces the formation of a complex between Ror 2 and Frizzled, resulting in Ser/Thr phosphorylation of Ror2 and the recruitment of Dvl, Axin, and GSK3B, the same machinery that mediates the Wnt3Ainduced phosphorylation of Lrp5/6 as discussed in the beginning of this article (Yamamoto et al. 2007; Grumolato et al. 2010). According to this model, Wnt $3 \mathrm{~A}$ and Wnt5A compete for binding to Frizzled. The identity of the Wnt ligand determines whether the Frizzled coreceptor will be Lrp5/6 or Ror2, thus dictating whether $\beta$-catenin-dependent or -independent signaling will be activated, respectively (Grumolato et al. 2010). In support of this model, Ror proteins have also been reported to bind to Frizzled receptors in C. elegans, Xenopus, and mammals (Oishi et al. 2003; Li et al. 2008; Nishita et al. 2010; Song et al.
Ryk and Ror RTK in Wnt Signal Transduction

2010). Accessory proteins may promote the use of one type of coreceptor over another. For example, the collagen triple-helix repeat containing protein 1 (Cthrc1) enhances the formation of a complex containing Frizzled and Ror2 (Yamamoto et al. 2008). It remains to be determined, however, whether Ror2 always functions as a coreceptor as proposed by this model.

It is well established that Wnt5a, unlike Wnt3a, has the capacity to inhibit $\beta$-catenindependent signaling. However, the mechanism underlying this inhibition remains controversial. Proposed explanations include competition with other Wnts for binding to Frizzled (Grumolato et al. 2010; Sato et al. 2010), down-regulation of $\beta$-catenin via the E3 ubiquitin ligase Siah2 (Topol et al. 2003), or inhibition downstream of $\beta$-catenin (Ishitani et al. 2003; Mikels and Nusse 2006; Verkaar et al. 2010). It has been reported that Wnt5A inhibits Wnt3A-induced $\beta$-catenin signaling via Ror2 (Mikels and Nusse 2006; Li et al. 2008); however, others report that Ror2 is not absolutely required for this inhibition (Grumolato et al. 2010; Sato et al. 2010; Ho et al. 2012). Elucidation of the relationship between Ror proteins and canonical Wnt signaling is further complicated by the ability of Ror proteins to modulate Wnt signaling independently of Wnt5A. In C. elegans, expression of the Ror extracellular domain (ECD) is sufficient to interfere with Wnt signaling by binding and sequestering Wnt ligands (Forrester et al. 2004; Green et al. 2007). Although a similar sequestration function has not been clearly shown for vertebrate Rors, ectopic expression of a membrane-tethered ECD modulates Wnt signaling in various vertebrate contexts (Hikasa et al. 2002; Nishita et al. 2010). Reports that Ror2 can potentiate canonical Wnt signaling further cloud the issue, although these reports are thus far limited to overexpression studies (Billiard et al. 2005; Li et al. 2008).

In contrast to Ror2, the function of Ror1 in mediating Wnt signals has been explored in very limited detail. Moreover, although Wnt5A has been reported to bind to Ror 1 in vitro (Fukuda et al. 2008), Rorl has also been implicated in various non-Wnt responses. For instance, Ror 1 was shown to interact with and be inhibited by 
J. Green et al.

Resistin, a cysteine-rich protein produced by mature adipocytes (Sanchez-Solana et al. 2012). As indicated, Ror1 is generally presumed to be a pseudokinase, its tyrosine phosphorylation either undetectable (Bicocca et al. 2012) or because of transphosphorylation by other kinases (Gentile et al. 2011).

The downstream effector mechanisms of Ror1 remain ill defined. For instance, in B-cell malignancies, cross talk between Ror 1 and the pre-B-cell receptor complex has been reported, with Ror1 activating small GTPases to promote survival signaling (Bicocca et al. 2012). In contrast, a dual function for Ror1 was shown in lung adenocarcinoma (Yamaguchi et al. 2012). Here, Ror1 was required to sustain EGFR/ ERBB3 signaling in a presumably kinase-independent manner. At the same time, Ror1 was responsible for Src phosphorylation and activation of PI3K/AKT signaling, suggesting that kinase-dependent functions for Ror1 should not be ruled out completely.

Summarizing, at present it remains incompletely understood just how promiscuous the interaction between the Ror receptors and their ligands, both Wnts and others, really is. Similar to the situation observed for Wnts and Fzds, it is unlikely that the Ror CRD will interact with only a single, specific ligand, but just how specificity in ligand/receptor interactions is achieved, particularly in the context of a complex multicellular organism, remains one of the outstanding questions in the Wnt field.

In both C. elegans and vertebrates, Ror proteins contribute to the orientation of cells within a tissue, a process known as planar cell polarity (PCP) (Green et al. 2008a; Yamamoto et al. 2008). In the murine limb bud, Wnt5A induces a complex between Ror2 and Vangl2, a core component of the PCP pathway, in a concentrationdependent manner. Thus, Ror proteins transmit directional information provided by a Wnt gradient to the PCP machinery in developing tissues. Likewise, Xenopus XRor2 regulates convergent extension, a PCP-related process (Hikasa et al. 2002; Schambony and Wedlich 2007).

In addition to modulating canonical Wnt signaling and regulating cell polarity, Ror2 is required for Wnt5A to mediate cell migration, a function that has been reported to involve protein kinase $\mathrm{C}$, JNK, and the actin-binding protein Filamin A (Nishita et al. 2006; Yamamoto et al. 2007; Nomachi et al. 2008; O’Connell et al. 2009). Ror2 signaling also contributes to the invasiveness of various human cancers including those of the skin (O'Connell et al. 2010), prostate (Yamamoto et al. 2010), bone (Enomoto et al. 2009; Yamagata et al. 2012), and kidney (Wright et al. 2009). This increased invasiveness has been associated with the increased expression of extracellular matrix remodeling enzymes called MMPs by Ror2-JNK or Ror2-cSrc signaling. Further complicating matters, Wnt5a was recently also shown to promote cancer cell invasion in a presumably Ror-independent manner by disrupting the association between $\mathrm{N}$-cadherin and $\beta$-catenin, thereby promoting $\beta$-catenin/TCF signaling (Grossmann et al. 2013).

Many other potential Ror1/2 signaling effectors have been reported in various contexts, but further study is required to determine when and how they are used and in what combinations. In addition to Src and Src family kinases (Akbarzadeh et al. 2008; Enomoto et al. 2009), these include Dlxin-1 (Matsuda et al. 2003),

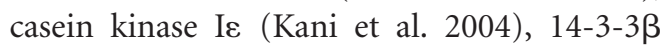
(Liu et al. 2007), NF-кB (Fukuda et al. 2008), and BMPR1b (Sammar et al. 2004). It also remains to be determined if and how any of these components are connected to the upstream Wnt signaling machinery. This includes the Dishevelled protein, which plays an important role in both $\beta$-catenin-dependent and -independent Wnt-signaling events and which can be phosphorylated in response to Wnt5a/Ror signaling (Ho et al. 2012).

\section{DERAILED/Ryk/lin-18}

The Derailed/Ryk/lin18 receptors form a family of conserved transmembrane molecules with an extracellular domain resembling the Wnt inhibitory factor (WIF) protein (Patthy 2000; Angers and Moon 2009; Fradkin et al. 2010). Similar to secreted Frizzled related proteins (SFRPs), WIFs are extracellular Wnt antagonists (Hsieh et al. 1999a). Unlike SFRPs, how- 
ever, the WIF Wnt-binding domain is different from the classic CRD domain that is observed in both FZD and Ror receptors (Fig. 1). Interestingly, it has been suggested that the WIF domain interacts directly with the lipid modification on the Wnt protein (Malinauskas et al. 2011), similar to the way in which the Fzd CRD domain was recently shown to engage in Wnt binding (Janda et al. 2012). The cytoplasmic portion of Derailed/Ryk/lin-18 has a tyrosine kinase motif, but according to the actual sequence, Derailed and Ryk are not considered to be active tyrosine kinase enzymes. This has been confirmed by functional assays (Yoshikawa et al. 2001; Inoue et al. 2004).

The mammalian Ryk gene was found by homology screens (Stacker et al. 1993), whereas the original identification of derailed was based on genetic screens in Drosophila for mutants that affect axon path finding in the embryo (Callahan et al. 1995; Bonkowsky et al. 1999). Derailed is also required for the specificity of muscle attachment sites (Callahan et al. 1996). A C. elegans homolog, lin-18, is critical for vulva development, in parallel to the Frizzled family member lin-17 (Inoue et al. 2004; Wang and Sommer 2011).

Of note, whereas the mammalian genome appears to harbor just a single Ryk gene (in addition to a Ryk pseudogene) (Halford et al. 1999), multiple derailed/Ryk/lin-18 family members exist in Drosophila. In addition to Derailed, these include the doughnut, which is itself also involved in muscle attachment formation (Lahaye et al. 2012). Yet another homolog, Derailed2, plays a role opposing Derailed1 during development of the Drosophila olfactory system (Sakurai et al. 2009).

A ligand of Derailed in these processes was initially not known, but the homology between the cell external domain of Derailed with WIF (Patthy 2000) suggested that Wnt proteins could interact with Derailed. Indeed, one of the Drosophila Wnt family members, DWnt5 (Fradkin et al. 1995), has genetic interactions with $D e$ railed (Yoshikawa et al. 2003; Fradkin et al. 2004). DWnt5 is expressed in a pattern similar to Derailed and the phenotypes of these genes resemble each other as well. In C. elegans, the
Wnt proteins LIN-44, MOM-2, and CWN-2 redundantly regulate P7.p patterning, suggesting that Ryk might respond to multiple Wnt ligands. As in Drosophila, the mammalian Ryk gene is required for axon guidance and neurite outgrowth ( $\mathrm{Lu}$ et al. 2004a; Keeble and Cooper 2006). More recently, mammalian Ryk was also shown to interact with the core planar cell polarity (PCP) machinery, and Ryk-deficient mice presented with typical PCP defects such as the misorientation of stereocilia in the inner ear (Macheda et al. 2012).

How do the Derailed/RYK/lin-18 receptors function molecularly? As mentioned above, all Derailed/RYK/lin-18 are catalytically inactive. Hence, Ryk may act as a coreceptor rather than as a primary signal transducing receptor. As a coreceptor, Derailed/RYK/lin-18 molecules may bind Wnts that are then cotargeted to other Wnt receptors. Indeed, whereas the intracellular kinase domains of Derailed/RYK/lin-18 proteins are largely dispensable for function, the extracellular WIF domains are not (Inoue et al. 2004; Taillebourg et al. 2005). Among the candidates for a receptor working with Derailed/RYK/lin 18 are, perhaps not surprisingly, the Frizzleds. In neurite outgrowth in mammalian cells, the Ryk molecule stimulates Frizzled activity, both in vivo and in cell culture assays ( $\mathrm{Lu}$ et al. 2004a). Moreover, in Xenopus, Ryk cooperates with Fzd7 and Wnt11 during gastrulation and convergent extension movements (Kim et al. 2008; Lin et al. 2010), suggesting some form of interaction. On the other hand, although the lin-18 (Ryk) and lin-17 (a Frizzled) genes in C. elegans both operate in vulva development, they are thought to act independently of each other (Inoue et al. 2004). As has been described for Ror2, Ryk might also couple directly to the core planar cell polarity pathway as it has also been shown to form a complex with and promote the stability of Vangl2 (Andre et al. 2012).

When it comes to the mechanism of action of Derailed/RYK/lin-18 receptors at the cytoplasmic side, there is also relatively little known. Surprisingly, Ryk was shown to undergo cleavage and, in response to Wnt-ligand stimulation, the carboxy-terminal fragment translocated to 
J. Green et al.

the nucleus (Lyu et al. 2008). Cleavage is mediated by $\gamma$-secretase and appears to be essential for the neuronal Ryk-mediated signal transduction events (Lyu et al. 2008). The carboxy-terminal fragment undergoes ubiquitination and degradation by the proteasome, in a way that is inhibited by Cdc37, a subunit of the molecular chaperone Hsp90 complex (Lyu et al. 2009). Inhibition may also require the Src protein kinase (Wouda et al. 2008). In the process of ubiquitination, the RYK molecule also interacts with the E3 ubiquitin ligase Mindbomb 1 (Berndt et al. 2011). The latter work also showed that Ryk can activate $\beta$-catenin signaling, suggesting yet another level of interactions among the various Wnt pathways (Berndt et al. 2011).

\section{CONCLUDING REMARKS}

In summary, much remains to be learned about the mechanism of action of both the Ror and Ryk tyrosine kinase receptor families. The fact that several of the main classes of Wnt receptors, including the Frizzleds, the RORs, and the RYKs, have ligand-binding domains that exist by themselves as secreted Wnt-binding factors, suggests a complex extracellular landscape of Wnts, secreted inhibitors, and receptors that may compete or assist each other in setting signaling levels and boundaries. But just how Ryk and Ror work as (co)receptors is still far from clear. It should also be stressed that additional non-Frizzled (co)receptors might still be out there. An example is the transmembrane protein PTK7/CCK4, which has an extracellular domain containing immunoglobulin repeats as well as an intracellular tyrosine kinase homology domain and which is required for the establishment of planar cell polarity in mammals ( $\mathrm{Lu}$ et al. 2004b; Yen et al. 2009). Moreover, in spite of the fact that it does not appear to contain a bona fide Wnt-binding domain, PTK7 has been shown to interact with some, but not other, Wnt ligands and to inhibit $\mathrm{Wnt} / \beta$-catenin signaling (Peradziryi et al. 2011). Given the multitude of experimental systems that can now be used, it is expected that significant progress will be made in understanding the involvement of these RTKs in development and disease.

\section{REFERENCES}

Afzal AR, Jeffery S. 2003. One gene, two phenotypes: ROR2 mutations in autosomal recessive Robinow syndrome and autosomal dominant brachydactyly type B. Hum Mutat 22: 1-11.

Afzal AR, Rajab A, Fenske CD, Oldridge M, Elanko N, Ternes-Pereira E, Tuysuz B, Murday VA, Patton MA, Wilkie AO, et al. 2000. Recessive Robinow syndrome, allelic to dominant brachydactyly type B, is caused by mutation of ROR2. Nat Genet 25: 419-422.

Akbarzadeh S, Wheldon LM, Sweet SM, Talma S, Mardakheh FK, Heath JK. 2008. The deleted in brachydactyly B domain of ROR2 is required for receptor activation by recruitment of Src. PLoS ONE 3: e1873.

Al-Shawi R, Ashton SV, Underwood C, Simons JP. 2001. Expression of the Ror 1 and Ror2 receptor tyrosine kinase genes during mouse development. Dev Genes Evol 211: $161-171$.

Andre P, Wang Q, Wang N, Gao B, Schilit A, Halford MM, Stacker SA, Zhang X, Yang Y. 2012. The Wnt coreceptor Ryk regulates Wnt/planar cell polarity by modulating the degradation of the core planar cell polarity component Vangl2. J Biol Chem 287: 44518-44525.

Angers S, Moon RT. 2009. Proximal events in Wnt signal transduction. Nat Rev Mol Cell Biol 10: 468-477.

Barna G, Mihalik R, Timar B, Tombol J, Csende Z, Sebestyen A, Bodor C, Csernus B, Reiniger L, Petak I, et al. 2011. ROR1 expression is not a unique marker of CLL. Hematol Oncol 29: 17-21.

Baskar S, Kwong KY, Hofer T, Levy JM, Kennedy MG, Lee E, Staudt LM, Wilson WH, Wiestner A, Rader C. 2008. Unique cell surface expression of receptor tyrosine kinase ROR1 in human B-cell chronic lymphocytic leukemia. Clin Cancer Res 14: 396-404.

Baskar S, Wiestner A, Wilson WH, Pastan I, Rader C. 2012. Targeting malignant $\mathrm{B}$ cells with an immunotoxin against ROR1. MAbs 4: 349-361.

Berndt JD, Aoyagi A, Yang P, Anastas JN, Tang L, Moon RT. 2011. Mindbomb 1, an E3 ubiquitin ligase, forms a complex with RYK to activate Wnt $/ \beta$-catenin signaling. J Cell Biol 194: 737-750.

Bhanot P, Brink M, Samos CH, Hsieh JC, Wang Y, Macke JP, Andrew D, Nathans J, Nusse R. 1996. A new member of the frizzled family from Drosophila functions as a Wingless receptor. Nature 382: 225-230.

Bicocca VT, Chang BH, Masouleh BK, Muschen M, Loriaux MM, Druker BJ, Tyner JW. 2012. Crosstalk between ROR1 and the Pre-B cell receptor promotes survival of $\mathrm{t}(1 ; 19)$ acute lymphoblastic leukemia. Cancer Cell 22: 656-667.

Billiard J, Way DS, Seestaller-Wehr LM, Moran RA, Mangine A, Bodine PV. 2005. The orphan receptor tyrosine kinase Ror2 modulates canonical Wnt signaling in osteoblastic cells. Mol Endocrinol 19: 90-101.

Bonkowsky JL, Yoshikawa S, O’Keefe DD, Scully AL, Thomas JB. 1999. Axon routing across the midline controlled by the Drosophila Derailed receptor. Nature 402: 540-544.

Callahan CA, Muralidhar MG, Lundgren SE, Scully AL, Thomas JB. 1995. Control of neuronal pathway selection by a Drosophila receptor protein-tyrosine kinase family member. Nature 376: 171-174. 
Callahan CA, Bonkovsky JL, Scully AL, Thomas JB. 1996. Derailed is required for muscle attachment site selection in Drosophila. Development 122: 2761-2767.

Carmon KS, Loose DS. 2010. Development of a bioassay for detection of Wnt-binding affinities for individual frizzled receptors. Anal Biochem 401: 288-294.

Chen W, ten Berge D, Brown J, Ahn S, Hu LA, Miller WE, Caron MG, Barak LS, Nusse R, Lefkowitz RJ. 2003. Dishevelled 2 recruits $\beta$-arrestin 2 to mediate Wnt5A-stimulated endocytosis of Frizzled 4. Science 301: 1391-1394.

Choudhury A, Derkow K, Daneshmanesh AH, Mikaelsson E, Kiaii S, Kokhaei P, Osterborg A, Mellstedt H. 2010 Silencing of ROR1 and FMOD with siRNA results in apoptosis of CLL cells. Br J Haematol 151: 327-335.

Clevers H, Nusse R. 2012. Wnt/ $\beta$-catenin signaling and disease. Cell 149: 1192-1205.

Daneshmanesh AH, Mikaelsson E, Jeddi-Tehrani M, Bayat AA, Ghods R, Ostadkarampour M, Akhondi M, Lagercrantz S, Larsson C, Osterborg A, et al. 2008. Ror1, a cell surface receptor tyrosine kinase is expressed in chronic lymphocytic leukemia and may serve as a putative target for therapy. Int J Cancer 123: 1190-1195.

Daneshmanesh AH, Hojjat-Farsangi M, Khan AS, JeddiTehrani M, Akhondi MM, Bayat AA, Ghods R, Mahmoudi AR, Hadavi R, Osterborg A, et al. 2012. Monoclonal antibodies against ROR1 induce apoptosis of chronic lymphocytic leukemia (CLL) cells. Leukemia 26: $1348-1355$.

Dave H, Anver MR, Butcher DO, Brown P, Khan J, Wayne AS, Baskar S, Rader C. 2012. Restricted cell surface expression of receptor tyrosine kinase ROR1 in pediatric Blineage acute lymphoblastic leukemia suggests targetability with therapeutic monoclonal antibodies. PLOS ONE 7: e52655.

Davidson G, Wu W, Shen J, Bilic J, Fenger U, Stannek P, Glinka A, Niehrs C. 2005. Casein kinase 1 y couples Wnt receptor activation to cytoplasmic signal transduction. Nature 438: 867-872.

DeChiara TM, Kimble RB, Poueymirou WT, Rojas J, Masiakowski P, Valenzuela DM, Yancopoulos GD. 2000. Ror2, encoding a receptor-like tyrosine kinase, is required for cartilage and growth plate development. Nat Genet 24: 271-274.

Edris B, Espinosa I, Muhlenberg T, Mikels A, Lee CH, Steigen SE, Zhu S, Montgomery KD, Lazar AJ, Lev D, et al. 2012. ROR2 is a novel prognostic biomarker and a potential therapeutic target in leiomyosarcoma and gastrointestinal stromal tumour. J Pathol 227: 223-233.

Endo M, Doi R, Nishita M, Minami Y. 2012. Ror family receptor tyrosine kinases regulate the maintenance of neural progenitor cells in the developing neocortex. $J$ Cell Sci 125: 2017-2029.

Enomoto M, Hayakawa S, Itsukushima S, Ren DY, Matsuo M, Tamada K, Oneyama C, Okada M, Takumi T, Nishita $\mathrm{M}$, et al. 2009. Autonomous regulation of osteosarcoma cell invasiveness by Wnt5a/Ror2 signaling. Oncogene 28: 3197-3208.

Fiedler M, Mendoza-Topaz C, Rutherford TJ, Mieszczanek J, Bienz M. 2011. Dishevelled interacts with the DIX domain polymerization interface of Axin to interfere with its function in down-regulating $\beta$-catenin. Proc Natl Acad Sci 108: $1937-1942$.
Forrester WC, Dell M, Perens E, Garriga G. 1999. AC. elegans Ror receptor tyrosine kinase regulates cell motility and asymmetric cell division. Nature 400: 881-885.

Forrester WC, Kim C, Garriga G. 2004. The Caenorhabditis elegans Ror RTK CAM-1 inhibits EGL-20/Wnt signaling in cell migration. Genetics 168: 1951-1962.

Fradkin LG, Noordermeer JN, Nusse R. 1995. The Drosophila Wnt protein DWnt-3 is a secreted glycoprotein localized on the axon tracts of the embryonic CNS. Dev Biol 168: 202-213.

Fradkin LG, van Schie M, Wouda RR, de Jong A, Kamphorst JT, Radjkoemar-Bansraj M, Noordermeer JN. 2004. The Drosophila Wnt5 protein mediates selective axon fasciculation in the embryonic central nervous system. Dev Biol 272: 362-375.

Fradkin LG, Dura JM, Noordermeer JN. 2010. Ryks: New partners for Wnts in the developing and regenerating nervous system. Trends Neurosci 33: 84-92.

Francis MM, Evans SP, Jensen M, Madsen DM, Mancuso J, Norman KR, Maricq AV. 2005. The Ror receptor tyrosine kinase CAM-1 is required for ACR-16-mediated synaptic transmission at the C. elegans neuromuscular junction. Neuron 46: 581-594.

Fukuda T, Chen L, Endo T, Tang L, Lu D, Castro JE, Widhopf GF 2nd, Rassenti LZ, Cantwell MJ, Prussak CE, et al. 2008. Antisera induced by infusions of autologous AdCD154-leukemia B cells identify ROR1 as an oncofetal antigen and receptor for Wnt5a. Proc Natl Acad Sci 105: 3047-3052.

Gentile A, Lazzari L, Benvenuti S, Trusolino L, Comoglio PM. 2011. Ror1 is a pseudokinase that is crucial for Metdriven tumorigenesis. Cancer Res 71: 3132-3141.

Green JL, Inoue T, Sternberg PW. 2007. The C. elegans ROR receptor tyrosine kinase, CAM-1, non-autonomously inhibits the Wnt pathway. Development 134: 4053-4062.

Green JL, Inoue T, Sternberg PW. 2008a. Opposing Wnt pathways orient cell polarity during organogenesis. Cell 134: $646-656$.

Green JL, Kuntz SG, Sternberg PW. 2008b. Ror receptor tyrosine kinases: Orphans no more. Trends Cell Biol 18: $536-544$.

Grossmann AH, Yoo JH, Clancy J, Sorensen LK, Sedgwick A, Tong Z, Ostanin K, Rogers A, Grossmann KF, Tripp SR, et al. 2013. The small GTPase ARF6 stimulates $\beta$-catenin transcriptional activity during WNT5A-mediated melanoma invasion and metastasis. Sci Signal 6: pra14.

Grumolato L, Liu G, Mong P, Mudbhary R, Biswas R, Arroyave R, Vijayakumar S, Economides AN, Aaronson SA. 2010. Canonical and noncanonical Wnts use a common mechanism to activate completely unrelated coreceptors. Genes Dev 24: 2517-2530.

Halford MM, Oates AC, Hibbs ML, Wilks AF, Stacker SA. 1999. Genomic structure and expression of the mouse growth factor receptor related to tyrosine kinases (Ryk). J Biol Chem 274: 7379-7390.

Hayashi Y, Hirotsu T, Iwata R, Kage-Nakadai E, Kunitomo H, Ishihara T, Iino Y, Kubo T. 2009. A trophic role for Wnt-Ror kinase signaling during developmental pruning in Caenorhabditis elegans. Nat Neurosci 12: 981-987. 
J. Green et al.

He X, Semenov M, Tamai K, Zeng X. 2004. LDL receptorrelated proteins 5 and 6 in Wnt $/ \beta$-catenin signaling: Arrows point the way. Development 131: 1663-1677.

Hikasa H, Shibata M, Hiratani I, Taira M. 2002. The Xenopus receptor tyrosine kinase Xror2 modulates morphogenetic movements of the axial mesoderm and neuroectoderm via Wnt signaling. Development 129: 5227-5239.

Ho HY, Susman MW, Bikoff JB, Ryu YK, Jonas AM, Hu L, Kuruvilla R, Greenberg ME. 2012. Wnt5a-Ror-Dishevelled signaling constitutes a core developmental pathway that controls tissue morphogenesis. Proc Natl Acad Sci 109: 4044-4051.

Hsieh JC, Kodjabachian L, Rebbert ML, Rattner A, Smallwood PM, Samos CH, Nusse R, Dawid IB, Nathans J. 1999a. A new secreted protein that binds to Wnt proteins and inhibits their activities. Nature 398: 431-436.

Hsieh JC, Rattner A, Smallwood PM, Nathans J. 1999b. Biochemical characterization of Wnt-frizzled interactions using a soluble, biologically active vertebrate Wnt protein. Proc Natl Acad Sci 96: 3546-3551.

Hudecek M, Schmitt TM, Baskar S, Lupo-Stanghellini MT, Nishida T, Yamamoto TN, Bleakley M, Turtle CJ, Chang WC, Greisman HA, et al. 2010. The B-cell tumor-associated antigen ROR1 can be targeted with T cells modified to express a ROR1-specific chimeric antigen receptor. Blood 116: 4532-4541.

Inoue T, Oz HS, Wiland D, Gharib S, Deshpande R, Hill RJ, Katz WS, Sternberg PW. 2004. C. elegans LIN-18 is a Ryk ortholog and functions in parallel to LIN-17/Frizzled in Wnt signaling. Cell 118: 795-806.

Ishitani T, Kishida S, Hyodo-Miura J, Ueno N, Yasuda J, Waterman M, Shibuya H, Moon RT, Ninomiya-Tsuji J, Matsumoto K. 2003. The TAK1-NLK mitogen-activated protein kinase cascade functions in the Wnt-5a/Ca ${ }^{2+}$ pathway to antagonize Wnt/ $\beta$-catenin signaling. $\mathrm{Mol}$ Cell Biol 23: 131-139.

Janda CY, Waghray D, Levin AM, Thomas C, Garcia KC. 2012. Structural basis of Wnt recognition by Frizzled. Science 337: 59-64.

Kani S, Oishi I, Yamamoto H, Yoda A, Suzuki H, Nomachi A, Iozumi K, Nishita M, Kikuchi A, Takumi T, et al. 2004. The receptor tyrosine kinase Ror2 associates with and is activated by casein kinase Iє. J Biol Chem 279: 5010250109.

Keeble TR, Cooper HM. 2006. Ryk: A novel Wnt receptor regulating axon pathfinding. Int J Biochem Cell Biol 38: 2011-2017.

Kennerdell JR, Fetter RD, Bargmann CI. 2009. Wnt-Ror signaling to SIA and SIB neurons directs anterior axon guidance and nerve ring placement in C. elegans. Development 136: 3801-3810.

Kim GH, Her JH, Han JK. 2008. Ryk cooperates with Frizzled 7 to promote Wnt11-mediated endocytosis and is essential for Xenopus laevis convergent extension movements. J Cell Biol 182: 1073-1082.

Lahaye LL, Wouda RR, de Jong AW, Fradkin LG, Noordermeer JN. 2012. WNT5 interacts with the Ryk receptors doughnut and derailed to mediate muscle attachment site selection in Drosophila melanogaster. PLoS ONE 7: e32297.

Lara E, Calvanese V, Huidobro C, Fernandez AF, MoncadaPazos A, Obaya AJ, Aguilera O, Gonzalez-Sancho JM,
Sanchez L, Astudillo A, et al. 2010. Epigenetic repression of ROR2 has a Wnt-mediated, pro-tumourigenic role in colon cancer. Mol Cancer 9: 170.

Li C, Chen H, Hu L, Xing Y, Sasaki T, Villosis MF, Li J, Nishita M, Minami Y, Minoo P. 2008. Ror2 modulates the canonical Wnt signaling in lung epithelial cells through cooperation with Fzd2. BMC Mol Biol 9: 11.

Li P, Harris D, Liu Z, Liu J, Keating M, Estrov Z. 2010. Stat3 activates the receptor tyrosine kinase like orphan receptor-1 gene in chronic lymphocytic leukemia cells. PLoS ONE 5: e11859.

Lin S, Baye LM, Westfall TA, Slusarski DC. 2010. Wnt5b-Ryk pathway provides directional signals to regulate gastrulation movement. J Cell Biol 190: 263-278.

Liu Y, Ross JF, Bodine PV, Billiard J. 2007. Homodimerization of Ror2 tyrosine kinase receptor induces $14-3-3(\beta)$ phosphorylation and promotes osteoblast differentiation and bone formation. Mol Endocrinol 21: 3050-3061.

Liu Y, Rubin B, Bodine PV, Billiard J. 2008. Wnt5a induces homodimerization and activation of Ror2 receptor tyrosine kinase. J Cell Biochem 105: 497-502.

Lu W, Yamamoto V, Ortega B, Baltimore D. 2004a. Mammalian Ryk is a Wnt coreceptor required for stimulation of neurite outgrowth. Cell 119: 97-108.

Lu X, Borchers AG, Jolicoeur C, Rayburn H, Baker JC, Tessier-Lavigne M. 2004b. PTK7/CCK-4 is a novel regulator of planar cell polarity in vertebrates. Nature 430: 93-98.

Lyashenko N, Weissenbock M, Sharir A, Erben RG, Minami Y, Hartmann C. 2010. Mice lacking the orphan receptor ror1 have distinct skeletal abnormalities and are growth retarded. Dev Dyn 239: 2266-2277.

Lyu J, Yamamoto V, Lu W. 2008. Cleavage of the Wnt receptor Ryk regulates neuronal differentiation during cortical neurogenesis. Dev Cell 15: 773-780.

Lyu J, Wesselschmidt RL, Lu W. 2009. Cdc37 regulates Ryk signaling by stabilizing the cleaved Ryk intracellular domain. J Biol Chem 284: 12940-12948.

Macheda ML, Sun WW, Kugathasan K, Hogan BM, Bower NI, Halford MM, Zhang YF, Jacques BE, Lieschke GJ, Dabdoub A, et al. 2012. The Wnt receptor Ryk plays a role in mammalian planar cell polarity signaling. $J$ Biol Chem 287: 29312-29323.

MacKeigan JP, Murphy LO, Blenis J. 2005. Sensitized RNAi screen of human kinases and phosphatases identifies new regulators of apoptosis and chemoresistance. Nat Cell Biol 7: 591-600.

Makino K, Goto Y, Sueyasu M, Futagami K, Kataoka Y, Oishi R. 1997. Micellar electrokinetic capillary chromatography for therapeutic drug monitoring of zonisamide. $J$ Chromatogr B Biomed Sci Appl 695: 417-425.

Malinauskas T, Aricescu AR, Lu W, Siebold C, Jones EY. 2011. Modular mechanism of Wnt signaling inhibition by Wnt inhibitory factor 1. Nat Struct Mol Biol 18: 886-893.

Mao J, Wang J, Liu B, Pan W, Farr GH 3rd, Flynn C, Yuan H, Takada S, Kimelman D, Li L, et al. 2001. Low-density lipoprotein receptor-related protein-5 binds to Axin and regulates the canonical Wnt signaling pathway. $\mathrm{Mol}$ Cell 7: 801-809.

Masiakowski P, Carroll RD. 1992. A novel family of cell surface receptors with tyrosine kinase-like domain. J Biol Chem 267: 26181-26190. 
Matsuda T, Nomi M, Ikeya M, Kani S, Oishi I, Terashima T, Takada S, Minami Y. 2001. Expression of the receptor tyrosine kinase genes, Ror1 and Ror2, during mouse development. Mech Dev 105: 153-156.

Matsuda T, Suzuki H, Oishi I, Kani S, Kuroda Y, Komori T, Sasaki A, Watanabe K, Minami Y. 2003. The receptor tyrosine kinase Ror2 associates with the melanoma-associated antigen (MAGE) family protein Dlxin-1 and regulates its intracellular distribution. J Biol Chem 278: 29057-29064.

Mikels AJ, Nusse R. 2006. Purified Wnt5a protein activates or inhibits $\beta$-catenin-TCF signaling depending on receptor context. PLoS Biol 4: el15.

Mikels A, Minami Y, Nusse R. 2009. Ror2 receptor requires tyrosine kinase activity to mediate Wnt5A signaling. $J$ Biol Chem 284: 30167-30176.

Morioka K, Tanikawa C, Ochi K, Daigo Y, Katagiri T, Kawano $\mathrm{H}$, Kawaguchi $\mathrm{H}$, Myoui A, Yoshikawa $\mathrm{H}$, Naka N, et al. 2009. Orphan receptor tyrosine kinase ROR2 as a potential therapeutic target for osteosarcoma. Cancer Sci 100: $1227-1233$

Nishita M, Yoo SK, Nomachi A, Kani S, Sougawa N, Ohta Y, Takada S, Kikuchi A, Minami Y. 2006. Filopodia formation mediated by receptor tyrosine kinase Ror2 is required for Wnt5a-induced cell migration. J Cell Biol 175: 555-562.

Nishita M, Itsukushima S, Nomachi A, Endo M, Wang Z, Inaba D, Qiao S, Takada S, Kikuchi A, Minami Y. 2010. Ror2/Frizzled complex mediates Wnt5a-induced AP-1 activation by regulating Dishevelled polymerization. Mol Cell Biol 30: 3610-3619.

Nomachi A, Nishita M, Inaba D, Enomoto M, Hamasaki M, Minami Y. 2008. Receptor tyrosine kinase Ror2 mediates Wnt5a-induced polarized cell migration by activating cJun $\mathrm{N}$-terminal kinase via actin-binding protein filamin A. J Biol Chem 283: 27973-27981.

Nomi M, Oishi I, Kani S, Suzuki H, Matsuda T, Yoda A, Kitamura M, Itoh K, Takeuchi S, Takeda K, et al. 2001 Loss of mRorl enhances the heart and skeletal abnormalities in mRor2-deficient mice: Redundant and pleiotropic functions of mRor1 and mRor2 receptor tyrosine kinases. Mol Cell Biol 21: 8329-8335.

O'Connell MP, Fiori JL, Baugher KM, Indig FE, French AD, Camilli TC, Frank BP, Earley R, Hoek KS, Hasskamp JH, et al. 2009. Wnt5A activates the calpain-mediated cleavage of filamin A. J Invest Dermatol 129: 1782-1789.

O'Connell MP, Fiori JL, Xu M, Carter AD, Frank BP, Camilli TC, French AD, Dissanayake SK, Indig FE, Bernier M, et al. 2010. The orphan tyrosine kinase receptor, ROR2, mediates Wnt5A signaling in metastatic melanoma. Oncogene 29: 34-44.

Oishi I, Takeuchi S, Hashimoto R, Nagabukuro A, Ueda T, Liu ZJ, Hatta T, Akira S, Matsuda Y, Yamamura H, et al. 1999. Spatio-temporally regulated expression of receptor tyrosine kinases, mRor1, mRor2, during mouse development: implications in development and function of the nervous system. Genes Cells 4: 41-56.

Oishi I, Suzuki H, Onishi N, Takada R, Kani S, Ohkawara B, Koshida I, Suzuki K, Yamada G, Schwabe GC, et al. 2003. The receptor tyrosine kinase Ror2 is involved in noncanonical Wnt5a/JNK signalling pathway. Genes Cells 8: $645-654$.
Oldridge M, Fortuna AM, Maringa M, Propping P, Mansour S, Pollitt C, DeChiara TM, Kimble RB, Valenzuela DM, Yancopoulos GD, et al. 2000. Dominant mutations in ROR2, encoding an orphan receptor tyrosine kinase, cause brachydactyly type B. Nat Genet 24: 275-278.

Patthy L. 2000. The WIF module. Trends Biochem Sci 25: $12-13$.

Peradziryi H, Kaplan NA, Podleschny M, Liu X, Wehner P, Borchers A, Tolwinski NS. 2011. PTK7/Otk interacts with Wnts and inhibits canonical Wnt signalling. EMBO J 30: 3729-3740.

Person AD, Beiraghi S, Sieben CM, Hermanson S, Neumann AN, Robu ME, Schleiffarth JR, Billington CJ Jr, van Bokhoven H, Hoogeboom JM, et al. 2010. WNT5A mutations in patients with autosomal dominant Robinow syndrome. Dev Dyn 239: 327-337.

Pinson KI, Brennan J, Monkley S, Avery BJ, Skarnes WC. 2000. An LDL-receptor-related protein mediates Wnt signalling in mice. Nature 407: 535-538.

Reddy UR, Phatak S, Pleasure D. 1996. Human neural tissues express a truncated Rorl receptor tyrosine kinase, lacking both extracellular and transmembrane domains. Oncogene 13: 1555-1559.

Sakurai M, Aoki T, Yoshikawa S, Santschi LA, Saito H, Endo K, Ishikawa K, Kimura K, Ito K, Thomas JB, et al. 2009. Differentially expressed Drl and Drl-2 play opposing roles in Wnt5 signaling during Drosophila olfactory system development. J Neurosci 29: 4972-4980.

Saldanha J, Singh J, Mahadevan D. 1998. Identification of a Frizzled-like cysteine rich domain in the extracellular region of developmental receptor tyrosine kinases. Protein Sci 7: 1632-1635.

Sammar M, Stricker S, Schwabe GC, Sieber C, Hartung A, Hanke M, Oishi I, Pohl J, Minami Y, Sebald W, et al. 2004. Modulation of GDF5/BRI-b signalling through interaction with the tyrosine kinase receptor Ror2. Genes Cells 9: $1227-1238$.

Sanchez-Solana B, Laborda J, Baladron V. 2012. Mouse resistin modulates adipogenesis and glucose uptake in 3T3L1 preadipocytes through the ROR1 receptor. Mol Endocrinol 26: 110-127.

Sato A, Yamamoto H, Sakane H, Koyama H, Kikuchi A. 2010. Wnt5a regulates distinct signalling pathways by binding to Frizzled2. EMBO J 29: 41-54.

Schambony A, Wedlich D. 2007. Wnt-5A/Ror2 regulate expression of XPAPC through an alternative noncanonical signaling pathway. Dev Cell 12: 779-792.

Schwarz-Romond T, Fiedler M, Shibata N, Butler PJ, Kikuchi A, Higuchi Y, Bienz M. 2007. The DIX domain of Dishevelled confers Wnt signaling by dynamic polymerization. Nat Struct Mol Biol 14: 484-492.

Song S, Zhang B, Sun H, Li X, Xiang Y, Liu Z, Huang X, Ding M. 2010. AWnt-Frz/Ror-Dsh pathway regulates neurite outgrowth in Caenorhabditis elegans. PLoS Genet 6.

Stacker SA, Hovens CM, Vitali A, Pritchard MA, Baker E, Sutherland GR, Wilks AF. 1993. Molecular cloning and chromosomal localisation of the human homologue of a receptor related to tyrosine kinases (RYK). Oncogene 8: 1347-1356.

Taillebourg E, Moreau-Fauvarque C, Delaval K, Dura JM. 2005. In vivo evidence for a regulatory role of the kinase 
J. Green et al.

activity of the linotte/derailed receptor tyrosine kinase, a Drosophila Ryk ortholog. Dev Genes Evol 215: 158-163.

Takeuchi S, Takeda K, Oishi I, Nomi M, Ikeya M, Itoh K, Tamura S, Ueda T, Hatta T, Otani H, et al. 2000. Mouse Ror2 receptor tyrosine kinase is required for the heart development and limb formation. Genes Cells 5: 71-78.

Tamai K, Semenov M, Kato Y, Spokony R, Liu C, Katsuyama Y, Hess F, Saint-Jeannet JP, He X. 2000. LDL-receptorrelated proteins in Wnt signal transduction. Nature 407: $530-535$.

Tauriello DV, Jordens I, Kirchner K, Slootstra JW, Kruitwagen T, Bouwman BA, Noutsou M, Rudiger SG, Schwamborn K, Schambony A, et al. 2012. Wnt/ $\beta$-catenin signaling requires interaction of the Dishevelled DEP domain and $\mathrm{C}$ terminus with a discontinuous motif in Frizzled. Proc Natl Acad Sci 109: E812-820.

Topol L, Jiang X, Choi H, Garrett-Beal L, Carolan PJ, Yang Y. 2003. Wnt-5a inhibits the canonical Wnt pathway by promoting GSK-3-independent $\beta$-catenin degradation. J Cell Biol 162: 899-908.

Tseng HC, Lyu PC, Lin WC. 2010. Nuclear localization of orphan receptor protein kinase (Ror1) is mediated through the juxtamembrane domain. BMC Cell Biol 11: 48 .

Tseng HC, Kao HW, Ho MR, Chen YR, Lin TW, Lyu PC, Lin WC. 2011. Cytoskeleton network and cellular migration modulated by nuclear-localized receptor tyrosine kinase ROR1. Anticancer Res 31: 4239-4249.

Tyner JW, Deininger MW, Loriaux MM, Chang BH, Gotlib JR, Willis SG, Erickson H, Kovacsovics T, O'Hare T, Heinrich $\mathrm{MC}$, et al. 2009. RNAi screen for rapid therapeutic target identification in leukemia patients. Proc Natl Acad Sci 106: 8695-8700.

Verkaar F, Blankesteijn WM, Smits JF, Zaman GJ. 2010 $\beta$-Galactosidase enzyme fragment complementation for the measurement of $\mathrm{Wnt} / \beta$-catenin signaling. FASEB $J$ 24: $1205-1217$.

Wang X, Sommer RJ. 2011. Antagonism of LIN-17/Frizzled and LIN-18/Ryk in nematode vulva induction reveals evolutionary alterations in core developmental pathways. PLoS Biol 9: e1001110.

Wehrli M, Dougan ST, Caldwell K, O’Keefe L, Schwartz S, Vaizel-Ohayon D, Schejter E, Tomlinson A, DiNardo S. 2000. Arrow encodes an LDL-receptor-related protein essential for Wingless signalling. Nature 407: 527-530.

Wilson C, Goberdhan DC, Steller H. 1993. Dror, a potential neurotrophic receptor gene, encodes a Drosophila homo$\log$ of the vertebrate Ror family of Trk-related receptor tyrosine kinases. Proc Natl Acad Sci 90: 7109-7113.

Wouda RR, Bansraj MR, de Jong AW, Noordermeer JN, Fradkin LG. 2008. Src family kinases are required for WNT5 signaling through the Derailed/RYK receptor in the Drosophila embryonic central nervous system. Development 135: 2277-2287.

Wright TM, Brannon AR, Gordan JD, Mikels AJ, Mitchell C, Chen S, Espinosa I, van de Rijn M, Pruthi R, Wallen E, et al. 2009. Ror2, a developmentally regulated kinase, promotes tumor growth potential in renal cell carcinoma. Oncogene 28: 2513-2523.

Yamada M, Udagawa J, Matsumoto A, Hashimoto R, Hatta T, Nishita M, Minami Y, Otani H. 2010. Ror2 is required for midgut elongation during mouse development. Dev Dyn 239: 941-953.

Yamagata K, Li X, Ikegaki S, Oneyama C, Okada M, Nishita M, Minami Y. 2012. Dissection of Wnt5a-Ror2 signaling leading to matrix metalloproteinase (MMP-13) expression. J Biol Chem 287: 1588-1599.

Yamaguchi TP, Bradley A, McMahon AP, Jones S. 1999. A Wnt5a pathway underlies outgrowth of multiple structures in the vertebrate embryo. Development 126: 12111223.

Yamaguchi T, Yanagisawa K, Sugiyama R, Hosono Y, Shimada Y, Arima C, Kato S, Tomida S, Suzuki M, Osada H, et al. 2012. NKX2-1/TITF1/TTF-1-induced ROR1 is required to sustain EGFR survival signaling in lung adenocarcinoma. Cancer Cell 21: 348-361.

Yamamoto H, Yoo SK, Nishita M, Kikuchi A, Minami Y. 2007. Wnt5a modulates glycogen synthase kinase 3 to induce phosphorylation of receptor tyrosine kinase Ror2. Genes Cells 12: 1215-1223.

Yamamoto S, Nishimura O, Misaki K, Nishita M, Minami Y, Yonemura S, Tarui H, Sasaki H. 2008. Cthrcl selectively activates the planar cell polarity pathway of Wnt signaling by stabilizing the Wnt-receptor complex. Dev Cell 15: 23-36.

Yamamoto H, Oue N, Sato A, Hasegawa Y, Yamamoto H, Matsubara A, Yasui W, Kikuchi A. 2010. Wnt5a signaling is involved in the aggressiveness of prostate cancer and expression of metalloproteinase. Oncogene 29: 20362046.

Yamamoto Y, Takeshita H, Sawa H. 2011. Multiple Wnts redundantly control polarity orientation in Caenorhabditis elegans epithelial stem cells. PLoS Genet 7: e1002308.

Yang J, Baskar S, Kwong KY, Kennedy MG, Wiestner A, Rader C. 2011. Therapeutic potential and challenges of targeting receptor tyrosine kinase ROR1 with monoclonal antibodies in B-cell malignancies. PLOS ONE 6: e21018.

Yen WW, Williams M, Periasamy A, Conaway M, Burdsal C, Keller R, Lu X, Sutherland A. 2009. PTK7 is essential for polarized cell motility and convergent extension during mouse gastrulation. Development 136: 2039-2048.

Yoshikawa S, Bonkowsky JL, Kokel M, Shyn S, Thomas JB. 2001. The derailed guidance receptor does not require kinase activity in vivo. J Neurosci 21: RC119.

Yoshikawa S, McKinnon RD, Kokel M, Thomas JB. 2003. Wnt-mediated axon guidance via the Drosophila Derailed receptor. Nature 422: 583-588.

Zeng X, Tamai K, Doble B, Li S, Huang H, Habas R, Okamura H, Woodgett J, He X. 2005. A dual-kinase mechanism for Wnt co-receptor phosphorylation and activation. Nature 438: 873-877.

Zhang S, Chen L, Cui B, Chuang HY, Yu J, Wang-Rodriguez J, Tang L, Chen G, Basak GW, Kipps TJ. 2012. ROR1 is expressed in human breast cancer and associated with enhanced tumor-cell growth. PLoS ONE 7: e31127.

Zinovyeva AY, Yamamoto Y, Sawa H, Forrester WC. 2008. Complex network of Wnt signaling regulates neuronal migrations during Caenorhabditis elegans development. Genetics 179: 1357-1371. 


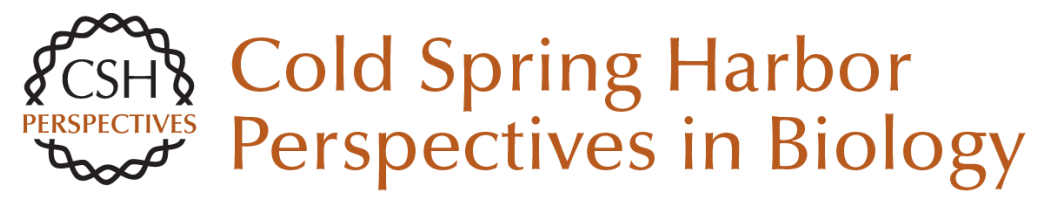

\title{
The Role of Ryk and Ror Receptor Tyrosine Kinases in Wnt Signal Transduction
}

\author{
Jennifer Green, Roel Nusse and Renée van Amerongen
}

Cold Spring Harb Perspect Biol 2014; doi: 10.1101/cshperspect.a009175 originally published online December 26, 2013

\section{Subject Collection Signaling by Receptor Tyrosine Kinases}

CSF-1 Receptor Signaling in Myeloid Cells

E. Richard Stanley and Violeta Chitu

The EGFR Family: Not So Prototypical Receptor

Tyrosine Kinases

Mark A. Lemmon, Joseph Schlessinger and

Kathryn M. Ferguson

Tie2 and Eph Receptor Tyrosine Kinase Activation and Signaling

William A. Barton, Annamarie C. Dalton, Tom C.M.

Seegar, et al.

The Spatiotemporal Organization of ErbB

Receptors: Insights from Microscopy

Christopher C. Valley, Keith A. Lidke and Diane S. Lidke

Insulin Receptor Signaling in Normal and

Insulin-Resistant States

Jérémie Boucher, André Kleinridders and $C$. Ronald Kahn

Central Role of RET in Thyroid Cancer

Massimo Santoro and Francesca Carlomagno

Receptor Tyrosine Kinase-Mediated Angiogenesis Michael Jeltsch, Veli-Matti Leppänen, Pipsa Saharinen, et al.
The Genesis of Tyrosine Phosphorylation Tony Hunter

Structure-Function Relationships of ErbB RTKs in the Plasma Membrane of Living Cells Donna J. Arndt-Jovin, Michelle G. Botelho and Thomas M. Jovin

Receptor Tyrosine Kinases: Legacy of the First

Two Decades Joseph Schlessinger

The Role of Ryk and Ror Receptor Tyrosine

Kinases in Wnt Signal Transduction Jennifer Green, Roel Nusse and Renée van Amerongen

Regulation of Receptor Tyrosine Kinase Ligand

Processing Colin Adrain and Matthew Freeman

Molecular Mechanisms of SH2- and

PTB-Domain-Containing Proteins in Receptor Tyrosine Kinase Signaling Melany J. Wagner, Melissa M. Stacey, Bernard A. Liu, et al.

Eph Receptor Signaling and Ephrins Erika M. Lisabeth, Giulia Falivelli and Elena B. Pasquale

For additional articles in this collection, see http://cshperspectives.cshlp.org/cgi/collection/

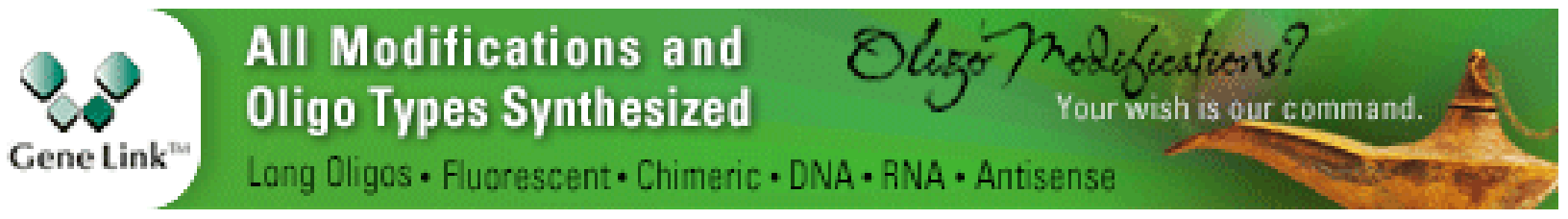




\section{Biology of the TAM Receptors \\ Greg Lemke}

Effects of Membrane Trafficking on Signaling by

Receptor Tyrosine Kinases

Marta Miaczynska

For additional articles in this collection, see http://cshperspectives.cshlp.org/cgi/collection/

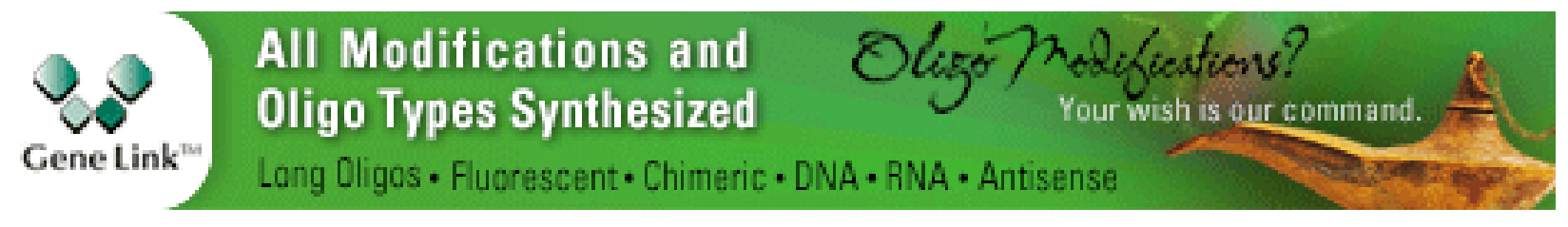

Copyright @ 2014 Cold Spring Harbor Laboratory Press; all rights reserved 